SCIENTIFIC WORK OF THE SMITHSONIAN INSTITUTION. ${ }^{1}$

Explorations and Researches.

THE resources of the Smithsonian Institution are at present too limited to permit of large grants for extensive explorations or investigations, but, so far as the income allows, aid is given in various lines of research work, and it is sometimes found possible to engage in expeditions likely to accomplish important results.

Through the National Museum, the Bureau of American Ethnology, and the Astrophysical Observatory, the institution has been enabled to carry on various biological, ethnological, and astrophysical researches during the year covered by the report.

Studies in Cambrian Geology and Palaeontology.

In the last report reference was made to studies of the older sedimentary rocks of the North American Continent which Dr. Walcott has been carrying on for the past twenty years. This work was continued in the Canadian Rockies during the field season of 1907. Early in July a camp outfit was secured at Field, British Columbia, and work begun on Mount Stephen. Subsequently sections were studied and measured at Castle Mountain, west of Banff, Alberta; at Lake Louise, south of Laggan, Alberta; and on Mount Bosworth, on the Continental Divide near Hector, British Columbia. Upward of 20,000 feet of strata were carefully examined and measured, and collections of fossils and rocks made from many localities. It was found that the Cambrian section included more than 12,000 feet of sandstones, shales, and limestones, and that the three great divisions of the Cambrian-the Lower, Middle, and Upper-were represented in the Bow River series and the Castle Mountain group. Characteristic fossils were found in each division.

\section{Aërial Navigation.}

Within the past year there has been a renewed interest in experiments in aërial navigation, to which the institution, through Dr. Langley, made notable contributions. Toward the end of the year the demand for literature on the subject so entirely exhausted the supply of papers on hand that a special edition of some of Dr. Langley's more popular memoirs was issued. It is gratifying to be able to say that his pioneer work in heavier-than-air machines, resulting as it did in the actual demonstration of the possibility of mechanical flight, has now received universal recognition.

Besides numerous popular papers, Dr. Langley wrote two technical works relating to the general subject of aërodromics, which form parts of an incomplete volume of the Smithsonian Contributions to Knowledge. The record of his experiments from 1893 to 1905 was kept by him partly in manuscript form and largely in the shape of voluminous notes and waste-books. These have been turned over to his principal assistant in this work, $\mathrm{Mr}$. C. M. Manly, who has been for some time engaged in preparing them for publication and adding such necessary information, especially on the engineering side, as comes within the immediate purview of Mr. Manly's work.

Meteor Crater of Canyon Diablo, Arizona.

A $n$ investigation of the remarkable crater-like depression at Coon Butte, near Canyon Diablo, Arizona, was made in 1907 by Dr. G. P. Merrill, head curator of geology in the National Museum, aided by a grant from the Smithsonian Institution. An article upon studies of this crater by other geologists appeared in NATURE of September 13 , r906. The "crater" is some three-fourths of a mile in diameter and 500 feet in depth in a region of undisturbed sedimentary rocks and remote from volcanoes. The object of the study was to determine, if possible, whether the crater was caused by volcanic action, as assumed by some investigators, or due to the impact of a mass of meteoric iron, as asserted by others.

From the available evidence Dr. Merrill concluded that the crater could not have been formed by volcanic action, all the observed phenomena being of a superficial nature. Some 300 feet of overlying limestone and 500 feet of sandstone have been shattered as by some powerful blow, and 1 From the Report of the Secretary of the Smithsonian Institution,
Dr. C. D. Walcott, for the year ending June 30 , 1908. the quartz particles in the sandstone in part fused, indicating a very high degree of heat. The deeper-lying sandstone, however, is entirely unchanged. These facts absolutely preclude the formation of the crater by any deepseated agency, and forces the conclusion that it resulted from the impact of a stellar body.

No record has been found of a meteoric fall comparable with this, the largest known meteorites, such as that from Cape York, Greenland, and the enormous irons from Oregon, having fallen under such conditions as scarcely to bury themselves. The nearest approach to the Canyon Diablo occurrence was that at Knyahinya, Hungary, where a $660-1 \mathrm{~b}$. stone penetrated the ground to a depth of II feet. No meteoritic mass of sufficient size to have made this enormous crater has been brought to light, but it is thought there still remains the possibility of its having become dissipated through the heat developed by its impact while travelling at a speed of many miles a second.

In his report Dr. Merrill goes very thoroughly into details. He has secured many specimens of the meteoritic irons and their associations from the locality, which are deposited in the U.S. National Museum. The specimens include a hitherto unrecognised type of meteoritic iron and a peculiar form of metamorphism in the siliceous sandstone of the region.

Mining operations carried on in the crater afforded special opportunity for this research. These operations were discontinued during the winter, but their resumption in May, 1908, presented a second opportunity for the observation of the unique phenomena at the crater, and Dr. Merrill was authorised to proceed again to Arizona to be present during this second, and probably final, series of drillings. The greatest depth reached during his stay at the crater was 842 feet, and the results of the examination of the ejectamenta thus secured confirmed the former conclusion.

\section{Alaskan Expedition.}

In the last report mention was made of an expedition to be made to the Yukon country in Alaska for the collection of the remains of large extinct vertebrates, particularly mammals. A Smithsonian expedition had been made to this region in the summer of 1904 by $\mathrm{Mr}$. Maddren, the results of which were published by the institution in 1905. The present expedition of 1907 was in charge of Mr. C. W. Gilmore, of the National Museum. The results of the explorations have been published in the Smithsonian Miscellaneous Collections.

$\mathrm{Mr}$. Gilmore was not successful in finding what was most desired, a fairly complete skeleton of a mammoth, but the expedition was by no means barren of results. He found that scattered remains of Pleistocene animals occur throughout the unglaciated region of Alaska and adjacent Canadian territory in the black muck accumulated in gulches and the valleys of the smaller streams, in the fine elevated clays of the Yukon silts and Kowak clays, and in the more recent fluvial and alluvial deposits. Some of the specimens are so well preserved that they could not have travelled far from the original place of interment, while many bones are broken, abraded, and waterworn. $\mathrm{Mr}$. Gilmore gives a list of the various genera and species of extinct vertebrates thus far reported from Alaska, followed by a brief review with a number of illustrations. $\mathrm{He}$ believes that when more perfect material is available it will be found, probably in all instances, to be quite distinct from the living forms. The skull of an Ovibos was found sufficiently complete to warrant its separation from the living form $O$. moschatus, to which nearly all musk-ox material from this region had previously been referred.

\section{Geology of the Alps.}

The investigation by Mr. Bailey Willis of the current theories of Alpine structure, under the grant approved in 1907, was successful in offering opportunities for consultation with leading European geologists, among whom were Rothpletz, Suess, Lugeon, Margerie, and Saccord. In cooperation with several distinguished students of the great problems of the Alps, Mr. Willis made detailed studies of critical districts, and was thus enabled to compare opposin theories by object-lessons on the ground. Mr. Willis's full report is expected early in 1909 . 
Absolute Measurement of Sound.

Dr. A. G. Webster announces the approaching completion of his research on the measurement of sound, which has been in progress for two years past. The investigation comprises an exhaustive treatment of the theory of the production of sound, with a description of a standard source, the transmission of sound through the air as modified by the effect of the ground, and its measurement by a receiving instrument. A description of experiments confirming the theory of Dr. Webster will be included in his finished report, with several practical applications, such as the examination of the sounds of speech, the diagnosis of deafness, the improvement of fog signals, and the testing of materials for the insulation of sound.

\section{Re-calculation of Atomic Weights.}

In February, 1908, Prof. F. W. Clarke, chairman of the International Commission on Atomic Weights, was authorised to begin the preparation of a third edition of his work on that subject, with the aid of a grant from the Smithsonian Institution. The second edition of Prof. Clarke's "Atomic Weights" was published in 1897, since which time the data on this subject have so largely increased as to render a new edition desirable. Some time will necessarily elapse before the completion of the work.

Properties of Matter at Temperature of Liquid Air.

In October, 1907, a Smithsonian grant was approved on behalf of Prof. E. L. Nichols, of Cornell University, for the continuation of his experiments on the properties of matter at the temperature of liquid air. Reports of the progress of this research are to be made from time to time in the recognised journals of physics, and, at the completion of the research, a memoir describing the in vestigation will be submitted to the Smithsonian Institution for consideration as to publication. It is believed that the prompt announcement of results in the way mentioned will be an immediate advantage to students, and that their publication as a whole by the institution will also prove of great service.

Flow of Air at High Pressure through a Nozzle.

The inquiry to determine the cooling effect of the nozzle expansion of air for large pressure differences, which has been conducted by Prof. W. P. Bradley, of Wesleyan University, with the aid of a grant from the Hodgkins fund of the institution, is announced as nearing completion. The investigation was intended specifically to determine whether the cooling process is due to the JouleThomson effect or to the performance of external work by the expanding air in pushing back the atmosphere from before the nozzle. The results of the inquiry make it clear that pressure is an important factor, and that the cooling effect increases very rapidly indeed as the initial temperature falls. Prof. Bradley is now engaged in an exact mathematical discussion of this research.

As to the apparatus employed, an interchanger of the Hampton type was so constructed, in vertical sections, that the amount of interchanger surface in actual use could be varied at will, from nothing to more than enough to induce liquefaction. In this manner it was possible to maintain the initial temperature constant, within one-third of a degree, at any desired point between $+20^{\circ}$ and $-120^{\circ}$, and the final temperature similarly constant between $+20^{\circ}$ and the temperature of liquefaction. The temperatures were measured by resistance thermometers placed close to the valves in the high- and low-pressure circuits. The pressures employed range from $500 \mathrm{lb}$. to $3000 \mathrm{lb}$. The expansion was exclusively to one atmosphere.

The inquiry is of interest as related to the functioning of air liquefiers in which the air is throttled by a valve and expands without performing external work, in the usual sense of that expression.

\section{Study of the Upper Atmosphere.}

A further grant from the Hodgkins fund was made to Prof. A. Lawrence Rotch, director of the Blue Hill Meteorological Observatory, to aid in the completion of his experiments with ballons-sondes at St. Louis. This was accomplished in October and November, 1907, under the direction of Mr. S. P. Fergusson.

The object of these latest ascensions, twenty-one in number, was to supply data for the high atmosphere during the autumn, a season when there are few observations, and also to establish a comparison with the results obtained simultaneously in Europe on the international term days in October and November. Prof. Rotch reports that all but two of the instruments used in these ascensions were recovered, and an examination of the record sheets indicates generally the presence, at an altitude exceeding eight miles, of the isothermal, or relatively warm stratum, which was found somewhat lower in summer. For example, on October 8 the minimum temperature of $90^{\circ} \mathrm{F}$. below zero was found at a height of 47,600 feet, whereas at the extreme altitude reached, namely, 54, 100 feet, the temperature had risen to $72^{\circ} \mathrm{F}$. below zero. Similarly, on October io the lowest temperature of $80^{\circ} \mathrm{F}$. below zero occurred at 39,700 feet, while $69^{\circ} \mathrm{F}$. below zero was recorded at 49,200 feet, the limit of this ascension, showing that the temperature inversion had come down about 8000 feet in two days.

The prevailing drift of the balloons during the autumn of 1907 was from the north-west, while in previous years they travelled more from the west. A description of the methods employed in launching seventy-seven ballonssondes from St. Louis, and a discussion of the results obtained, will soon appear in the Annals of the Astronomical Observatory of Harvard College.

\section{Air Sacs of the Pigeon.}

For several years there have been in progress under the general direction of Prof. von Lendenfeld, of the University of Prague, aided by grants from the Hodgkins fund, various investigations bearing upon animal flight. The results of one of these investigations, on the air sacs of the pigeon, by Bruno Müller, was published during the past year in the Smithsonian Miscellaneous Collections. The author summarises the conclusions of his studies as follows :-

I do not consider the air sacs, including the air cavities of bones, as organs having a positive and special function, but rather as a system of empty interspaces. Their value lies in their emptiness-that is, in their containing nothing that offers resistance or has an appreciable weight.

Flying is the highest form of locomotion, and as such only possible to a body of high mechanical efficiency. Our most effective machines are by no means compact and solid, but composed of parts as strong as possible in themselves and arranged in the most appropriate manner. The interspaces between the parts are left empty and taken up by air.

The Sauropsida, at the time they obtained the power of flight, became adapted to its mechanical requirements, and thereby similar to the efficient machines mentioned above; they divested themselves of all superfluous material, filling the body spaces thus obtained with air sacs. While the body wall, adapting itself to the mechanical requirement, became a compact, hollow cylinder serving as a support for the organs of movement, the mobility of the parts was assured by surrounding them with air sacs.

The lengthening of the neck, produced by quite a different adaptation, made necessary an increase in the quantity of air moved during respiration. This demand was met by air currents generated through a rhythmical change in the volume of the air sacs. The connection of the air sacs with the lungs is a consequence of their phylogenetic development, which is repeated in their embryological development, and has no physiological significance other than that the air sacs assist in renewing the air in the trachea.

\section{Preservation of Archaeological Sites.}

Attention has been directed previously to what had been done toward the preservation of archæological objects on the public domain from destruction by vandals and relic hunters, and toward making these antiquities accessible under proper rules and regulations. Under the terms of an Act of Congress approved June 8, 1906, uniform regu- 
lations for its administration were prepared by the Secretaries of the Interior, War, and Agriculture, with the cooperation of the Smithsonian Institution, and were promulgated on December 28,1906 , in the form printed in the last report. Under Rule 8, applications for permits are referred to the Smithsonian Institution for recommendation. During the past year several such applications have been acted upon. The conservation of the nation's archæological possessions was regulated by law none too soon to prevent further mutilation or useless destruction of interesting antiquities in many places.

The President of the United States, by executive proclamation during the year, made several additions to the list of national monuments, including three of archæological interest:-(x) the Tonto National Monument in Arizona, where there are two cliff-dwellings not vet reported on; (2) the Gila Cliff-dwellings National Monument in the Gila National Forest in New Mexico, comprising a group of cliff-dwellings; and (3) the Grand Canyon National Monument, which includes a large number of cliff-dwellings, pueblos, dwelling sites, and burial places in the Grand Canyon of the Colorado.

Casa Grande Ruin in Arizona.

In 1906 Congress granted an appropriation of 3000 dollars to be expended under the supervision of the secretary of the Smithsonian Institution for the preservation of the Casa Grande ruin in Pinal County, near Florence, Ariz., and for the excavation of the reservation. An account of the work accomplished by Dr. Fewkes up to June 30, 1907 , was published in the Smithsonian Miscellaneous Collections under date of October 25, 1907. The work done during the past fiscal year, under a second appropriation, is noted in an appendix of the present report. The largest structure excavated at Casa Grande is a building 200 feet long with eleven rooms, the massive walls enclosing a plaza. In the central room there is a seat called by the Pima Indians "the seat of Montezuma." The ruins at Casa Grande are found to be very much more extensive than was anticipated, and their permanent preservation is of great archæological importance.

In addition to the work of excavation, preservation, and repair of the cliff-dwellings and other prehistoric ruins in the Mesa Verde National Park in Colorado, studies have been made of the prehistoric culture of the Gila Valley, outside the Casa Grande Reservation. Dr. J. Walter Fewkes, who directed the Mesa Verde explorations, has prosecuted this later research also, and will submit an account in detail of what he has done for publication by the institution.

Bureau of American Ethnology.

The Burcau of American Ethnology has continued its investigations among the Indian tribes of the country begun more than a quarter of a century ago. Since it has not been possible to study all of the tribes in detail, a sufficient number have been taken as types to stand for all. The work accomplished in securing knowledge of these tribes has been recorded in the annual reports of the bureau, and the results obtained have been published, so far as circumstances will permit, in bulletins of the bureau. Many manuscripts are preserved in the archives of the bureau. To the present time there have been collected data relating to some sixty families of linguistic stocks and upward of 300 tribes. During the past year this fund of knowledge was added to through researches carried on in Arizona, New Mexico, Colorado, Texas, Minnesota, Pennsylvania, and Ontario.

For the first time the study of native Indian music was seriously taken up by the bureau in connection with certain investigations relating to the grand medicine ceremony of the Chippewa on the White Earth Reservation, Minn. The phonograph was employed in recording the songs. Records of songs were also secured from members of various Indian delegations visiting the capital.

This study and recording of the Indian tribes is not only of national importance, but urgent. The native American race, one of the four races of men, is fast disappenring. and the processes of obliteration are sure. If authoritative investigations are not made now, they never can be made with any like degree of accuracy or of thoroughness. It is a work the nation owes to science, to the Indian race, and to itself. It is a work worthy of a great nation, and one which can be carried on systematically only by a nation. Through the researches of the bureau the world is not only securing, while possible, a permanent record of one of the great races of men now dying out, but is gaining a knowledge of the Indian for practical purposes of administration and in the interest of humanity.

\section{Astrophysical Observatory.}

At Washington the observation of the relative brightness of different parts of the sun's disc has gone forward as there was opportunity. Improved methods of observing and reducing these observations have been adopted. Preparations for observing the absorption of water vapour in long columns of air, for the region of the spectrum where rays are chiefly emitted by the earth, have been carried to such a state that preliminary measurements have been made. The investigation is being carried on with a column of moist air about 400 feet in length.

A bolometric study of the solar corona was made on Flint Island, in the Southern Pacific, during the eclipse of January 3, 1908. The intensity and quality of sunlight was determined within twenty-five minutes of totality, both before and after, and during totality measurements were made at five different regions of the corona and on the dark moon. A general summary of the results of these and other observations follows:--

\section{Intensity of Rays (observed through Glass).}

$\begin{array}{llll}\text { Sun near zenith, Flint Island } \ldots & \ldots & \begin{array}{c}\text { Intensity for unit } \\ \text { angular area } \\ \text { 10,000,000 }\end{array} \\ \text { Sky } 20^{\circ} \text { from sun, Flint Island } & \ldots & 140 \\ \text { Sky far from sun, Flint Island... } & \ldots & 3 \mathrm{I} \\ \text { Sky average, Flint Island } \ldots & \ldots & 62 \\ \text { Sky average, Mount Wilson, Cal. } & \ldots & 15 \\ \text { Moon at night, Flint Island .. } & \ldots & 12(?) \\ \text { Moon during eclipse, Flint Island } & \ldots & 0 \\ \text { Corona }{ }^{7} \text { radius from sun } & \ldots & \ldots & 13 \\ \text { Corona radius from sun } & \ldots & \ldots & 4 \\ \text { Corona } \frac{1}{3} \text { radius from sun } & \ldots & \ldots & 0\end{array}$

When we recall the extreme brightness of the sky within a single degree of the sun, as compared with that $20^{\circ}$ away, and consider also the figures just given, it seems very unlikely that the corona will ever be observed without an eclipse.

The nature of the radiation of the inner corona has been supposed by some to be principally reflected solar radiation, by others to be principally due to the incandescence of particles heated by reason of their proximity to the sun, by others to be principally luminescence perhaps similar to the aurora, and by some as a combination of all these kinds of radiation.

The spectrum of the corona is mainly continuous, but has some inconspicuous bright lines, and in its outer part has dark solar lines. Undoubtedly there is sunlight reflected by the matter of the corona, and no less surely the corona must be hot. As for the idea of luminescence by electrical discharge, though the streamers of the corona are a reminder of the aurora, one hesitates to recommend an explanation involving a thing so little understood, so that we will here speak only of the incandescence and reflection of the corona as sources of its brightness. The bolometric results indicate that the coronal radiation differs but little in quality from that of the sun, and is, in fact, far richer than the reflected ravs of the moon in visible light, although less rich than sky light.

Great advantage having been found in 1905 and 1906 in making solar-constant investigations on Mount Wilson as well as in Washington, and strong evidence having been secured there of the considerable variability of the slin, it was concluded to continue in 1908 the expedition to Mount Wilson in order to secure as many observations of the solar constant as possible for the study of solar changes.

The frequent observation of the solar constant during a period of years at least equal to the sun-spot cycle was regarded by the late director, Dr. Langley, as a research 
of great importance. Having proved by the expeditions of 1905 and 1906 that the variation of solar radiation is highly probable, and also that numerous days suitable for solar-constant observations were found in the months from May to November on Mount Wilson, it is now proposed to erect on a small, well-isolated plot of ground leased from the Carnegie Institution a fireproof observing shelter to be occupied by Smithsonian observers each year during the months mentioned.

The annual report of the board of regents of the Smithsonian Institution, showing the operations, expenditures, and condition of the institution for the year ending June 30 , $190 \%$, has also been received. As is customary with these handsome volumes, the greater part of the available space, which here runs to 726 pages, is devoted to the general appendix, composed of important papers by men of science of different nationalities. Among papers included in this appendix may be mentioned two Royal Institution lectures, that of the Hon. Charles A. Parsons, F.R.S., on the steam turbine on land and at sea, and that of Prof. J. A. Fleming, F.R.S., on recent contributions to electric-wave telegraphy. Other papers by British men of science include that of Prof. J. W. Gregory, F.R.S., on the geology of the inner earth-igneous ores, being his address as president of the geological section of the British Association at the Leicester meeting in I907; Mr. G. G. Chisholm's paper to the Royal Geographical Society, on inland waterways; that of Dr. D. H. Scott, F.R.S., on the present position of Palæozoic botany; and Mr. Henry Balfour's, on the fire piston. As is customary with these volumes, the illustrations are numerous and excellent.

\section{UNIVERSITY AND EDUCATIONAL INTELLIGENCE.}

THE chair of chemistry in the United College of the University of St. Andrews will be vacant at the end of the summer session on account of the resignation of Prof. $T$. Purdic owing to ill-health.

THE Senate of the University of Glasgow has decided to confer the honorary degree of LL.D. upon Dr. C. S, Sherrington, F.R.S., professor of physiology, Liverpool University, and Mr. W. H. Maw, editor of Engineering, and past-president of the Royal Astronomical Society.

InDUSTRIAL education, says the Pioneer Mail, is receiving a considerable amount of attention in the Central Provinces. During the last school year three students were granted State scholarships and sent to England, and one was given a scholarship to study under the directorgeneral of the Geological Survey. As it is difficult to secure qualified candidates for State technical scholarships, tenable in England, scholarships have been instituted to enable students to take the preliminary course in textile industries at the Victoria Institute in Bombay, but the question of establishing similar scholarships at Sibpur Engineering College has been deferred pending the settlement of the scheme for starting a technical college or school at Nagpur for engineering and mining.

AMERICAN universities and colleges continue to benefit from the munificence of wealthy citizens in the United States. A recent issue of Science announces that Yale University has received a gift of ro,oool. from an unknown donor for the purpose of establishing a memorial to the late Prof. Ely. Hamilton College is to receive a bequest of ro,oool. from Mrs. Annie P. Burgess, of New York City, who died about three years ago, leaving for educational and charitable purposes upward of 40,000 . This included 200ol. to Columbia University and to Barnard College for scholarships. After making some other specific bequests, she left the remainder of her estate to Hamilton College, Columbia University, and Barnard College. Among the bequests left by the late Mrs. Emma Cummings, of East Hampton, L.I., are 50ool. to Dartmouth College and 50ool. to Bowdoin College. The late Dr. Charles H. Roberts, of Highland, N.J., in his will provided for the founding of five scholarships of $48 l$. annually at Cornell University. Finally, Harvard University has received a gift of $30,000 l$. for the endowment of the University chapel.

$$
\text { No. } 2056 \text {, VOL. } 80]
$$

ThE report of the Board of Education for the vear I907- $\delta$ has now been published (Cd. 4566). Referring to the further education required by those who have already taken as full advantage of the facilities afiorded in elementary or secondary schools as their circumstances permit, the report states that the position is one of promise; the record of performance in all sections of the work is improving steadily, there is a fairly widespread recognition of existing shortcomings, and much serious effort is being made to overcome the difficulties inher nt in the case. The machinery for the education of those who can give their whole time to study, including technical study, until they reach manhood, is already in existence. In particular centres and in relation to particular occupations there is a sufficient supply of adequately prepared students to enable the teaching institutions to develop their power to the fuil. Others still suffer from the inadequacy of this supply and from the difficulty of retaining their students long enough to complete the allotted courses. In each type of school improvement is observable in several directions; students are coming up better prepared and with several years in hand for study, technical colleges are adjusting their teaching more directly to the requirements of the related occupations, and employers are finding it of advantage to secure the services of young men who have had the technical training the colleges afford. There is, the report maintains, sufficient cvidence that the teaching institutions are capable of raising the standard of their work when they have the opportunity. Attention is directed also to some aspects of evening-school organisation. It is a plain duty at the present time, says the report, to increase the number of trained teachers available for work in evening schools who are capable of bringing their teaching to bear directly upon some of the courses of instruction required in these schools in their areas.

ABundant evidence of the growing desire on the part of our educational authorities to adapt the instruction provided in elementary schools to the future needs of the providen is given in the latest report (Cd. 4566) of the Board of Education. For instance, the report shows that the tendency to organise rural education so that it may be a real preparation for rural life is a growing one. In one of the eastern counties (Lindsey) a rural education subcommittee has been appointed to report to the Education Committee on the subject. In this district the demand for small holdings under the recent Act has been active, and it is satisfactory that the authority should have recognised in this way the important place that must be given to education preparatory to rural life if small holdings are the report points out, to be successful. It is to be efficient, the teachers must that if rural education is to be efficient, the teachers must be trained properly for the work. To meet this need for suitable training, candidates for the preliminary examination of the Board of Education for the certificate can now take a course of nature-study alternatively to the course of elementary secide more inducement to secondary and this should provide more inducement to secondary schools to include these subation, candidates can now over, for the certificate ex botany or follow their natureeither continue their course of botany or follow their naturestudy by a course of rural science and courses and Saturday classes for teachers held at the agricultural colleges can afford a direct preparation for the certificate examination. The course of rural science, introduced as an optional subject for training colleges, has so far only been adopted by one college, and it is doubtful whether, in view of the already crowded curriculum, many of the colleges of the already crowded curriculum, me rural course. To provide an alternative method of preparing teachers for work in rural schools, the Board has expressed willingwess to approve an agricultural or horticultural college as ness to approve an agricultural or horticultural college as an institution affording already the ordinary for students who have us to the present little advantage has been taken of this facility, but now that certain education authorities are considering the establishment of special rural schools, and are beginning to recognise that for rural (evening) school work special qualifications are necessary, it seems likely that advantage will be taken of it. 